\title{
ANALISIS EFEKTIFITAS SISTEM PENERBITAN SURAT PENYEDIAAN DANA PADA BADAN PENGELOLA KEUANGAN DAN ASET DAERAH KABUPATEN MINAHASA
}

\author{
Sampoel Johanes Nofry ${ }^{1}$, Jullie J Sondakh ${ }^{2}$,Winston Pontoh ${ }^{3}$ \\ ${ }^{123}$ Jurusan Akuntansi, Fakultas Ekonomi dan Bisnis, Universitas Sam Ratulangi Manado, Jl. Kampus Bahu, \\ Manado 95115, Indonesia
}

Email :sampoelnofri@gmail.com

\begin{abstract}
The Letter of Provision of Funds is the first step in the cash disbursement transactions for the Unit of Work Device Area within a region. The system contained in the process for issuing letters of Provision of Funds has been determined by the Minister of Home Affairs regulation number 21 year 2011. This study aims is to determine how the effectiveness of the system applied to the Regional Financial and Asset Management Agency of Minahasa District in issuing the Letter of Provision of Funds based on SE.903/316/BAKD. The result of the research shows that the Regional Financial and Asset Management Agency of Minahasa has been effective in issuing letter of provision of funds in accordance with the Regulation of the Minister of Home Affairs Number 21 Year 2011 SE.903/316/BAKD concerning guidelines on regional financial management.
\end{abstract}

Keywords: analysis; effectiveness; system; cash disbursement; letter of provision of funds.

\section{PENDAHULUAN}

Era reformasi saat ini telah membawa beberapa perubahan dalam ketatanegaraan di negara ini.Salah satu perubahan tersebut adalah diberikannya kewenangan kepada setiap daerah untuk menyelenggarakan otonomi daerah sebagaimana diatur dalam undang-undang nomor 22 dan 25 tahun 1999. Otonomi daerah menuntut pemerintahan daerah untuk lebih memberikan pelayanan publik yang didasarkan pada asas-asas pelayanan publik yang meliputi transparansi, akuntabilitas, kondisional, partisipasif, kesamaan hak, keseimbangan hak dan kewajiban demi tercapainya good governance.

Perubahan yang paling mendasar terjadi di pemerintah daerah terutama dalam hal pengelolaan keuangan daerah. Perubahan yang terjadi mulai dari sistem penganggaran, sistem perbendaharaan, sistem pembukuan hingga pada sistem pertanggungjawaban laporan keuangan atas dana yang dikelola. Sebelum era reformasi, laporan perhitungan APBD berdiri sendiri dan terpisah dari pertanggungjawaban kepala daerah, bentuk laporan APBD terdiri atas perhitungan APBD, nota perhitungan serta ringkasan perhitungan pendapatan dan belanja, serta sistem yang digunakan untuk membuat laporan masih menggunakan sistem manual administrasi. Setelah adanya reformasi, laporan perhitungan APBD dan pertanggungjawaban Kepala Daerah digabung menjadi satu, untuk bentuk laporannya yaitu berupa laporan perhitungan APBD, nota perhitungan, laporan arus kas dan neraca.

Adanya penerapan otonomi daerah, maka pemerintah pusat menetapkan beberapa peraturan terkait dengan sistem dan prosedur akuntansi keuangan daerah. Hal itu digunakan untuk membantu pemerintah daerah dalam kegiatan pencatatan dan pengelolaan keuangan daerah. Sistem dan prosedur akuntansi yang terdapat di pemerintah daerah tertulis di dalam Peraturan Menteri dalam negeri no. 13 tahun 2006 tentang pedoman pengelolaan keuangan daerah yang selanjutnya dijabarkan dalam surat edaran nomor SE.900/316/BAKD yang mencakup pedoman sistem dan prosedur penatausahaan dan akuntansi, pelaporan dan pertanggungjawaban keuangan daerah, yang kemudian peraturan tersebut mengalami dua kali 
perubahan yaitu perubahan pertama Peraturan Menteri dalam negeri no. 59 tahun 2007 dan perubahan kedua yaitu Peraturan Pemerintah dalam negeri no. 21 tahun 2011.

Setiap organisasi atau perusahaan yang sehat pasti memiliki sistem akuntansi baik yang untuk pendapatan kas maupun pengeluaran kas.Sistem akuntansi adalah metode dan prosedur untuk mencatat dan melaporkan informasi keuangan yang disediakan bagi perusahaan atau suatu organisasi bisnis.Sistem akuntansi itu tidak hanya berlaku di perusahaan atau organisasi bisnis saja tetapi juga berlaku pada instansi-instansi pemerintahan.Sistem akuntansi yang berlaku di instansi-instansi pemerintah biasa disebut akuntansi sektor publik. Pembaharuan manajemen keuangan daerah di era otonomi daerah ini, ditandai dengan perubahan yang sangat mendasar mulai dari sistem penganggarannya, perbendaharaan sampai kepada pertanggungjawaban laporan keuangannya.

Pertanggungjawaban laporan keuangan daerah sebelum bergulirnya otonomi daerah hanya berupa laporan perhitungan anggaran dan nota perhitungan dan sistem yang digunakan untuk menghasilkan laporan tersebut adalah manual admisnistrasi keuangan daerah yang diterapkan sejak tahun 1981.Dalam sistem akuntansi pemerintahan ditetapkan entitas pelaporan dan entitas akuntansi yang menyelenggarakan sistem akuntansi pemerintah daerah.Pejabat pengelola keuangan daerah (PPKD) dan satuan kerja pengelola keuangan daerah (SKPKD) dan sistem akuntansi satuan kerja perangkat daerah (SKPD) dilaksanakan oleh pejabat penatausahaan keuangan satuan kerja perangkat daerah (PPK-SKPD).

Pasal 308 dan 309 dalam Permendagri nomor 21 tahun 2011 tentang pedoman pengelolaan keuangan daerah, mengamanatkan bahwa menteri dalam negeri melakukan pembinaan dan pengawasan pengelolaan keuangan daerah kepada pemerintah daerah antara lain pemberian dokumen sistem pengelolaan keuangan daerah. Dalam rangka mengimplementasi Permendagri nomor 21 tahun 2011 tentang pedoman pengelolaan keuangan daerah, menteri dalam negeri melalui direktorat jenderal bina administrasi melakukan fasilitas dengan menerbitkan SE.900/316/BAKD yang mencakup pedoman sistem dan prosedur penatausahaan dan akuntansi, pelaporan dan pertanggungjawaban keuangan daerah.

\section{TINJAUAN PUSTAKA}

Akuntansi pemerintahan. sebagai suatu aktivitas pemberian jasa untuk menyediakan informasi keuangan pemerintah berdasarkan proses pencatatan, pengklaifikasian, pengikhtisaran suatu transaksi keuangan pemerintah serta penafsiran atas informasi keuangan tersebut Bachtiar (2002:3). Akuntansi pemerintahan adalah sebuah kegiatan jasa dalam rangka menyediakan informasi kuantitatif terutama yang bersifat keuangan dari entitas pemerintah guna pengambilan keputusan ekonomi yang nalar dari pihak-pihak yang berkepentingan atas berbagai alternatif arah tindakan Sitorus (2015). Akuntansi pemerintahan merupakan pelayanan publik dalam pemberian jasa khususnya dalam penyediaan informasi keuangan pemerintah mulai dari pencatatan sampai pertanggung jawaban.

Pengelolaan Keuangan Daerah. Dalam penjelasan undang-undang nomor 17 tahun 2003 tentang keuangan negara dinyatakan bahwa pendekatan yang digunakan dalam merumuskan keuangan negara adalah dari sisi objek, subjek, proses, dan tujuan. Dari sisi objek, yang dimaksud dengan keuangan negara meliputi semua hak dan kewajiban negara yang dapat dinilai dengan uang, termasuk kebijakan dan kegiatan dalam bidang fiskal, moneter dan pengelolaan kekayaan negara yang dipisahkan, serta segala sesuatu baik berupa uang, maupun berupa barang yang dapat dijadikan milik negara berhubung dengan pelaksanaan hak dan kewajiban tersebut. Dari sisi subjek, yang dimaksud dengan keuangan negara meliputi seluruh subjek yang memiliki/menguasai objek sebagaimana tersebut di atas, yaitu: pemerintah pusat, pemerintah daerah, perusahaan negara/daerah, dan badan lain yang ada kaitannya dengan keuangan negara. Dari sisi proses, keuangan negara mencakup seluruh 
rangkaian kegiatan yang berkaitan dengan pengelolaan objek sebagaimana tersebut di atas mulai dari perumusan kebijakan dan pengambilan keputusan sampai dengan pertanggunggjawaban.

Analisis adalah proses mencari dan menyusun secara sistematis data yang diperoleh dari hasil wawancara, catatan lapangan, dan bahan-bahan lain, sehingga dapat mudah dipahami, dan temuannya dapat diinformasikan kepada orang lain Ointu (2016). Analisis adalah suatu kegiatan untuk memperoleh suatu data yang selanjutnya disampaikan kepada orang lain.

Efektivitas.adalah pemanfaatan sumber daya, sarana dan prasarana dalam jumlah yang secara sadar ditetapkan sebelumnya untuk menghasilkan jumlah barang atas jasa kegiatan yang dijalankannya Efektivitas menunjukan keberhasilan dari segi tercapai tidaknya sasaran yang telah ditetapkan. Jika hasil kegiatan semakin mendekati sasaran, berarti makin tinggi efektivitasnya Siagian (2001:4).

Surat Penyediaan Dana.merupakan langkah awal dalam transaksi pengeluaran kas untuk Satuan Kerja Perangkat Daerah (SKPD) dalam suatu daerah. Sistem yang terdapat dalam proses penerbitan surat penyediaan dana sudah di tentukan oleh Peraturan Menteri Dalam Negeri Nomor 21 Tahun 2011.

1. PPKD Menyerahkan dokumen kas Pemerintah Daerah dan DPA SKPD kepada Kuasa bendahara umum daerah

2. Kuasa BUD meyiapkan Rancangan SPD

3. Kuasa BUD menyerahkan rancangan SPD kepada PPKD.

4. PPKD mengotorisasikan rancangan SPD dan menyerahkan SPD kepada Pengguna Anggaran/Kuasa

\section{Penelitian Terdahulu}

Tuerah (2013) dengan judul Evaluasi Pelaksanaan Sistem dan Prosedur Penerimaan dan Pengeluaran Kas Dinas Kependudukan dan Pencatatan Sipil Minahasa Tenggara.Tujuannya untuk mengetahui Sistem dan Prosedur Penerimaan dan Pengeluaran Kas pada Dinas Kependudukan dan Pencatatan Sipil Minahasa Tenggara.Metode yang digunakan adalah deskriptif.Hasil penelitiannya yaitu pelaksanaan Sistem yang dibuat sudah layak digunakan, serta prosedur yang ada sudah memadai. Penelitian juga dilakukan Languju (2015) dengan judul Evaluasi Pelaksanaan Sistem Dan Prosedur Pengeluaran Kas Pada Dinas Perindustrian dan Perdangangan Provinsi Sulawesi Utara.Tujuannya Untuk mengetahui efektifitas system dan prosedur pengeluaran kas pada Dinas Perindustrian dan Perdangangan sesuai dengan Permendagri No.13Tahun 2006.Metode yang digunakan adalah deskriptif.Hasil penelitiannya yaitu system dan prosedur pengeluaran kas dilaksanakan berpedoman pada Permendagri No. 13 Tahun 2006 tentang Pedoman Pengelola Keuangan Daerah.

\section{METODE PENELITIAN}

\subsection{Jenis Penelitian}

Jenis data penelitian ini merupakan jenis penelitian deskriptif - kualitatif, yaitu suatu metode yang digunakan untuk menggambarkan yang sebenarnya berdasarkan apa yang nampak. Biasanya dilakukan analisis yang dapat memberikan gambaran yang lebih jelas mengenai objek yang diteliti.

Sumber Data. Sumber data yaitu : 1). Data Primer, data primer adalah data yang diperoleh dengan survei lapangan yang menggunakan semua metode pengumpulan data original (Kuncoro, 2014:149). 2). Data Sekunder, data sekunder adalah data yang telah dikumpulkan oleh lembaga pengumpul data dan dipublikasikan kepada masyarakat pengguna data (Kuncoro, 2014:149). 


\subsection{Metode Analisis}

Metode Analisis yang dipakai dalam penelitian ini adalah analisis deskriptif.untuk mengetahui bagaimana efektifitas system dan prosedur penerbitan surat penyediaan dana yang dilakukan pada Badan Pengelolaan Keuangan dan Aset Daerah Kabupaten Minahasa.

\section{HASIL PENELITIAN DAN PEMBAHASAN}

\subsection{Hasil Penelitian}

Dari hasil penelitian yang diperoleh, sistem penerbitan Surat Penyediaan Dana pada Badan Pengelolaan Keuangan dan Aset Daerah Kabupaten Minahasa adalah sebagai berikut :

1. Penyiapan Dokumen. PPKD menyerahkan dokumen anggaran kas pemerintah daerah dan DPA SKPD kepada Bidang Anggaran, dalam hal ini Bdang Anggaran Badan Pengelolaan Keuangan dan Aset Daerah Minahasa diberi kuasa oleh BUD untuk menjalankan tugas BUD dalam Penerbitan Surat Penyediaan Dana Pada SKPD yang berada dalam lingkungan Daerah Kabupaten Minahasa.

2. Membuat Rancangan SPD. Bidang Anggaran menyiapkan rancangan SPD segera setelah menerima Rancangan DPA SKPD dan anggaran kas SKPD. Rancangan SPD yang dibuat itu akan berisi jumlah penyediaan dana yang dibutuhkan. Setelah bidang anggaran menyiapkan rancangan SPD, Bidang Anggaran menyerahkan SPD kepada Pengguna Anggaran/Kuasa Pengguna Anggaran.

3. Penyerahan SPD kepada PPKD. Rancangan yang dibuat oleh Kuasa BUD melalui Bidang Anggaran, diserahkan kepada PPKD untuk ditandatangani yang terlebih dahulu diparaf oleh Kepala Bidang Anggaran dan Kuasa BUD.

4. Penyerahan SPD kepada Pengguna Anggaran. Setelah PPKD menerima Rancangan SPD yang dibuat oleh Bidang Anggaran, selanjutnya PPKD meneliti draft SPD yang diajukan oleh kuasa BUD dalam hal ini Bidang Anggaran, maka PPKD melakukan otoritas SPD untuk selanjutnya diserahkan kepada Pengguna Anggaran.

5. Penerbitan SPD. PPKD selanjutnya menerbitkan lembar SPD untuk diserahkan kepada pengguna anggaran/kuasa pengguna anggaran.SPD dibuat menjadi 2 lembar, lembar pertama untuk pengguna anggaran, dan lembar yang kedua dijadikan sebagai arsip.

\subsection{Pembahasan}

Sistem penerbitan Surat Penyediaan Dana pada Badan Pengelolaan Keuangan dan Aset Daerah Kabupaten Minahasa sudah sesuai dengan peraturan Menteri Dalam Negeri Nomor 21 Tahun 2011 SE.900/316/BAKD.

\section{Penyiapan Dokumen}

1. Permendagri SE.900/316/BAKD :

PPKD menyerahkan dokumen anggaran kas pemerintah daerah dan DPA SKPD kepada kuasa BUD.

2. Badan Pengelolaan Keuangan dan Aset Daerah Kabupaten Minahasa :

PPKD menyerahkan dokumen anggaran kas pemerintah daerah dan DPA SKPD kepada Bidang Anggaran, dalam hal ini Bdang Anggaran Badan Pengelolaan Keuangan dan Aset Daerah Minahasa diberi kuasa oleh BUD untuk menjalankan tugas BUD dalam Penerbitan Surat Penyediaan Dana Pada SKPD yang berada dalam lingkungan Daerah Kabupaten Minahasa.

\section{Membuat Rancangan SPD}

1. Permendagri SE.900/316/BAKD

PPKD dalam rangka manajemen kas menerbitkan SPD.SPD disiapkan oleh Kuasa BUD untuk ditandatangani oleh PPKD dan diserahkan kepada Pengguna Anggaran/Kuasa pengguna Anggaran.

2. Badan Pengelolaan Keuangan dan Aset Daerah Kabupaten Minahasa : 
Bidang Anggaran menyiapkan rancangan SPD segera setelah menerima Rancangan DPA SKPD dan anggaran kas SKPD. Rancangan SPD yang dibuat itu akan berisi jumlah penyediaan dana yang dibutuhkan. Setelah bidang anggaran menyiapkan rancangan SPD, Bidang Anggaran menyerahkan SPD kepada Pengguna Anggaran/Kuasa Pengguna Anggaran.

\section{Penyerahan SPD kepada PPKD}

1. Permendagri SE.900/316/BAKD

Rancangan SPD yang dibuat oleh Kuasa BUD, diserahkan kepada PPKD untuk ditandatangani yang terlebih dahulu diparaf oleh kepala bidang anggaran dan kuasa BUD.

2. Badan Pengelolaan Keuangan dan Aset Daerah Kabupaten Minahasa :

Rancangan yang dibuat oleh Kuasa BUD melalui Bidang Anggaran, diserahkan kepada PPKD untuk ditandatangani yang terlebih dahulu diparaf oleh Kepala Bidang Anggaran dan Kuasa BUD.

\section{Penyerahan SPD kepada Pengguna Anggaran}

1. Permendagri SE.900/316/BAKD

PPKD mengotorisasikan rancangan SPD dan menyerahkan SPD kepada pengguna anggaran/kuasa pengguna anggaran.

2. Badan Pengelolaan Keuangan dan Aset Daerah Kabupaten Minahasa :

Setelah PPKD menerima Rancangan SPD yang dibuat oleh Bidang Anggaran, selanjutnya PPKD meneliti draft SPD yang diajukan oleh kuasa BUD dalam hal ini Bidang Anggaran, maka PPKD melakukan otoritas SPD untuk selanjutnya diserahkan kepada Pengguna Anggaran.

\section{Penerbitan SPD}

1. Permendagri SE.900/316/BAKD

SPD dibuat menjadi 2 rangkap :

a. Lembar pertama untuk Pengguna Anggaran/Kuasa Pengguna Anggaran.

b. Lembar kedua sebagai Arsip.

2. Badan Pengelolaan Keuangan dan Aset Daerah Kabupaten Minahasa :

PPKD selanjutnya menerbitkan lembar SPD untuk diserahkan kepada pengguna anggaran/kuasa pengguna anggaran.SPD dibuat menjadi 2 lembar, lembar pertama untuk pengguna anggaran, dan lembar yang kedua dijadikan sebagai arsip.

\section{KESIMPULAN DAN SARAN}

\subsection{Kesimpulan}

Demikianlah hasil dari penelitian yang dilakukan pada Badan Pengelola Keuangan da

Aset Daerah Kabupaten Minahasa dan Berdasarkan hasil penelitian dan pembahasan mengenai efektifitas sistem penerbitan surat penyediaan dana pada Badan Pengelolaan Keuangan dan Aset Daerah kabupaten minahasa maka kesimpulannya adalah Efektifitas Sistem Penerbitan Surat Penyediaan Dana pada Badan Pengelolaan Keuangan dan Aset Daerah kabupaten minahasa telah sesuai dengan Peraturan Menteri Dalam Negeri Nomor 13 Tahun. Kekurangan dalam penelitian ini yaitu tidak adanya dokumentasi saat wawaancara dengan Kabid bidang anggaran pada badan pengelola keuangan dan aset daerah kabupaten Minahasa karena kabid bidang anggaran tidak bersedia untuk di ambil dokumentasi dengan alas an yang sepantasnya.Kekurangan berikutnya yaitu tidak adanya contoh surat penyediaan dana dari badan pengelola keuangan dan aset daerah kabupaten Minahasa karena masih bersifat tertutup, peneliti hanya melampirkan contoh surat penyediaan dana yang diambil melalui media sosial. 


\subsection{Saran}

Kemudian berikut Beberapa hal yang perlu diperhatikan oleh Badan Pengelolaan Keuangan dan Aset Daerah kabupaten minahasa yaitu :

1. Meningkatkan dan mempertahankan efektifitas sistem penerbitan surat penyediaan dana pada Badan Pengelolaan Keuangan dan Aset Daerah Kabupaten Minahasa.

2. Hendaknya dalam pelaksanaan pengelolaan keuangan tetap memperhatikan adanya perubahan-perubahan Undang Undang atau aturan aturan yang baru kedepannya.

\section{DAFTAR PUSTAKA}

Bahtiar A. (2002). Akuntansi Pemerintahan, Jakarta : Salemba Empat.

Kuncoro.2014. Metode Riset Untuk Bisnis dan Ekonomi.. Jakarta. Edisi 4 Erlangga

Languju G, V., Tinangon J., R, J, Pusung. (2015). Analisis Pelaksanaan Sistem dan Prosedur Pengeluaran Kas Pada Dinas Perindustrian dan Perdangan Provinsi Sulawesi Utara. JURNAL EMBA 3(1). https://ejournal.unsrat.ac.id/index.php/emba/article/view/7809/7372

Ointu M, R., dan Budiarso, N, S. (2016). Evaluasi Pelaksanaan Sistem dan Prosedur Pengeluaran Kas Uang Persedian Pada DPPKAD Kab. Bolaang Mongondow Selatan. JURNAL EMBA 4(3). https://ejournal.unsrat.ac.id/index.php/emba/article/view/11157/10747

Peraturan Menteri Dalam Negeri No. 21 Tahun 2011 SE 900/316 BAKD. Tentang Pedoman Pengelolaan Keuangan Daerah. Jakarta

Sitorus S., Kalangi, L., Walandouw, S, K. (2015). Analisis kesiapan penerapan standar akuntansi pemerintahan berbasis akrual berdasarkan PP. No 71 tahun 2010 pada dinas pendapatan pengelolaan keuangan dan barang milik daerah Kota Tomohon. JURNAL EMBA 3(1). https://ejournal.unsrat.ac.id/index.php/emba/article/view/5753

Siagian, S, P. (2001). Manajemen Sumber Daya Manusia. Jakarta, Bumi Aksara,

Tuerah F, S. (2013). Evaluasi Pelaksanaan Sistem dan Prosedur Penerimaan dan Pengeluaran Kas Dinas Kependudukan dan Pencatatan Sipil Minahasa Tenggara. JURNAL EMBA 1(3).https://ejournal.unsrat.ac.id/index.php/emba/article/view/1997

Tamboto J, A., Tinangon, J., Elim, I. (2015). Evaluasi pelaksanaan sistem dan prosedur penerimaan kas pada dinas pendapatan, pengelolaan keuangan dan barang milik daerah $\begin{array}{llll}\text { Kota Tomohon. JURNAL } & \text { 3(4). }\end{array}$ https://ejournal.unsrat.ac.id/index.php/emba/article/view/11157

Undang-undang No. 17 tahun 2003. Tentang Keuangan Negara. Jakarta Undang-undang No. 1 Tahun 2004. Tentang Perbendaharaan Negara. Jakarta Undang undang nomor 22 tahun 1999. Tentang Pemerintahan Daerah. Jakarta 